\title{
Subjective Well-Being of Employees During COVID-19 Pandemic in Terms of Self-Leadership
}

\author{
Nurul Amaliah Jasmal ${ }^{1,}$ Rezky Ariany Aras ${ }^{2,}$ Elvita Bellani ${ }^{3}$ \\ ${ }^{1}$ Psychology Department, Faculty of Medicine, Hasanuddin University \\ ${ }^{2}$ Psychology Department, Faculty of Medicine, Hasanuddin University \\ ${ }^{3}$ Psychology Department, Faculty of Medicine, Hasanuddin University \\ *Corresponding author Email: Liaamaliah34@gmail.com
}

\begin{abstract}
During the COVID-19 pandemic, some changes made employees feel dissatisfied, afraid, and worried at work. This study aims to examine the contribution of self-leadership to employees' subjective well-being during the COVID-19 pandemic. This research uses a quantitative method with a causality correlational design. The sample in this study was 127 employees. The instruments used in this study are satisfaction with life and a scale of positive and negative experience to measure subjective well-being, and a self-leadership questionnaire to measure self-leadership. The data analysis technique used is simple linear regression analysis, with a significant contribution value of $11.4 \%$ with the value of $r=0.337$ ( $p<0.001$ ) for self-leadership and cognitive aspects of subjective well-being and $8.9 \%$ with the value of $r=0.298$ ( $p<0.005)$ for self-leadership and affective aspects of subjective well-being. These results indicate that self-leadership contributes significantly to employees' subjective well-being during the COVID-19 pandemic. Based on the research results, an improvement in self-leadership on employees affects the increase in cognitive and affective subjective well-being aspects. An increase in self-leadership is expected to support employees' subjective well-being at work during the COVID-19 pandemic.
\end{abstract}

Keywords: Self-Leadership, Subjective Well-Being, Employees, COVID-19.

\section{INTRODUCTION}

Corona Virus Disease in 2019 (COVID-19) has become a global pandemic appearing in Wuhan, China, at the end of 2019. While in Indonesia, the first COVID-19 case appeared on March 2, 2020. As a result of the COVID-19 pandemic, the government made regulations contained in Government Regulation No. 21 of 2020 concerning large-scale social restriction (PSBB) policies, namely reduced or limited activities outside the home, and almost all offices or companies implement a work from home system.

Based on the insight talenta article [1] in April 2020, changes and disturbances occur during work from home in the COVID-19 pandemic. The first impact is interference from third parties; many parties can break employees' focus while working at home, such as family and neighbors. The second impact is inadequate facilities. When working directly in the office, the company provides the best facilities that can be used by employees, such as the internet network. When working from home, facilities such as an internet network are unavailable. Another change is that there is no apparent limit regarding working hours. Employees work fewer scheduled hours and lack written regulations when working from home.

Based on a survey conducted by Aritonang [2], it was found that working from home does not support a comfortable working atmosphere and does not have adequate facilities such as an internet network. The survey results also show that some respondents are dissatisfied with their work because working from home does not help develop themselves. The survey results also show that employees do not have clarity on working hours when working from home.

Success in carrying out duties and responsibilities as employees cannot be separated from the employees' welfare. Welfare can be achieved when employees work optimally and have a sense of happiness in the workplace 
[3]. However, based on the survey results above, employees who work from home have considerable pressure compared to when they work from the office because of the new working conditions and the less supportive environment when working from home. So there is a decrease in employee welfare while working from home. Pratiwi, Pertiwi, and Andriany [4] found that the subjective well-being level of employees who did WFH was at a low level of $39 \%$ and a medium level of $27 \%$, and a high level of $34 \%$. So researchers need to examine the subjective well-being of employees during the COVID-19 pandemic.

A survey conducted by researchers on employees at a company in Makassar showed that $80 \%$ of employees who filled out the questionnaire felt a change in their work situation during the COVID-19 pandemic. Changes in the situation, such as work procedures, become complex, challenging, and lack communication with co-workers. The absence of clarity in working hours increases workload and worries during work.

Based on interviews, the change in the work situation made employees feel dissatisfied and unhappy while working in a COVID-19 pandemic. Employees considered that the work results were not following the desired expectations, making employees unable to function optimally. Some employees work from the office, making employees feel afraid, worried, and insecure while working. Based on the results of the initial data stated previously and related theoretical studies, it can be concluded that there are problems with employees' subjective well-being during the COVID-19 pandemic.

Subjective well-being is an individual's cognitive and affective evaluation in assessing aspects of life consisting of life satisfaction, security and comfort, and happiness [5]. An individual's subjective evaluation of his life that includes concepts such as job satisfaction, pleasant emotions, feelings of fulfillment, satisfaction with domains such as marriage, work, and the highs and lows of emotions is called subjective well-being [6]

Individuals show high subjective well-being when they feel satisfied with their lives and often experience more joy and happiness than negative emotions such as sadness and anger [7]. Happiness can only be judged by the individual concerned. Individuals who feel positive emotions will judge their life as a pleasant life. On the other hand, individuals who feel negative emotions will consider their lives unpleasant [8].
The JD-R model was first proposed by Bakker \& Demerouti. This theoretical model explains that the resources owned by the company (job resources) and the resources of the individual (personal resources) interact with the workload of the company (job demands). Bakker $\&$ Demerouti [9] state that job demands are conditions of employees based on workload. Job resources can assist employees in overcoming job demands and can assist employees in learning, growth, or personal development [10]. Job resources include wages, feedback, support from superiors, clarity of roles in work, empowerment, and job autonomy. Bakker \& Demerouti [11] personal resources are a positive evaluation of resilience, which refers to an individual's ability to control and positively impact the surrounding environment.

Based on the phenomena obtained by researchers and the results of initial data, working during the COVID-19 pandemic made several work changes. These changes, such as work procedures, become complex, challenging, and lack communication with co-workers, and there are no precise working hours. From this change in the work situation, the company's resources and the individual, in this case, the employee himself, are not appropriately met, making it difficult for employees to cope with the workload while working. So it takes more effort to meet the existing resources. One of the personal resources needed by employees is self-leadership.

Manz [12] suggests that self-leadership is the ability to manage and influence oneself to build direction and do productive things to achieve personal goals. Selfleadership refers to the influence exerted by oneself to achieve one's internal motivation [13].

When individuals have self-leadership in themselves, they will be committed to the organization, innovate for the advancement of work, feel satisfied with their work, and help individuals correct inappropriate behavior when doing a job and help individuals avoid mistakes in working by preparing everything well [14]. Rahmawaty \& Rochmah [15] suggest that self-leadership is an effective way to improve performance. Although the individual feels that the work he is doing is not fun or is perceived as having a high risk, when the individual is balanced in carrying out the elements of self-leadership, the performance results are still good.

Research conducted by Kantonen [16] explains that self-leadership and subjective well-being increase entrepreneurial self-development. This study found that self-leadership is the primary key to increasing efficiency and improving entrepreneur performance. Self-leadership is a behavior that is influenced mainly by the individual's internal, so that self-leadership helps individuals increase 
intrinsic motivation. Individuals with good intrinsic motivation for self-management will experience a stronger sense of well-being and subjective well-being. Research conducted by Dolbier et al. [17] explains that self-leadership is related to the level of health, wellbeing, and personal resilience.

Based on the explanation of the phenomenon, the results of previous research, and the results of interviews conducted, the researcher wants to conduct further research that can empirically describe how much self-leadership contributes to employees' subjective well-being during the COVID-19 pandemic.

\subsection{Subjective Well-Being}

Subjective well-being is an individual's evaluation of his life, related to satisfaction with the domains of work and marriage and the emotions felt, both positive and negative [6]. Subjective well-being is an individual assessment of the whole life [18]. Diener, Lucas, and Oishi [5] suggest that subjective well-being is a cognitive and affective evaluation in life.

Diener [8] suggests two aspects of subjective wellbeing: cognitive and affective aspects. The affective aspect refers to the emotional experience felt by the individual. The emotional experience felt both positive and negative emotional feelings [19]. Feelings of emotions that are felt are obtained from the individual's response to an experienced event. The affective aspect of subjective well-being is an emotional reaction felt by individuals to events in their lives [20]. The cognitive aspect is the result of an individual's cognitive evaluation related to his life. Cognitive evaluation is carried out when individuals provide conscious evaluations and assess satisfaction in their overall lives regarding job satisfaction, interests, and relationships [20]. The cognitive aspect is also said to be an assessment of life satisfaction. The assessment of life satisfaction is based on a comparison of the current state (reality) and the standards of the individual himself [19].

\subsection{Self-Leadership}

Self-leadership influences oneself to do productive things to achieve personal goals [12]. Self-leadership influences oneself to build self-direction and motivation to do or complete tasks. So those individual goals are achieved [21]. Manz \& Sims [13] suggested that self-leadership refers to the influence given by oneself to achieve self-motivation (internal motivation).
Houghton \& Neck [22] suggest three aspects of selfleadership: (1) Behavioral-focused strategies focus on behavior shown to increase self-awareness by directing and managing behavior so that the work process becomes more enjoyable. (2) Natural reward strategies emphasize the fun aspect of a given task or activity. This strategy focuses on the fun aspects of the given task or activity. This is useful for increasing motivation at work so that work becomes more enjoyable and individuals can focus their attention on their tasks. (3) Constructive thought pattern strategies focus on efforts to build and change mindsets using self-analysis and improving belief systems by evaluating and replacing irrational beliefs and assumptions, building a positive image of performance, doing self-talk positively, as well as using scripts. This strategy involves creating and maintaining functional patterns of thinking; through self-analysis, individuals can identify, deal with, and respond to something more.

\subsection{Subjective Well-Being and Self-Leadership}

The relationship between self-leadership and subjective well-being can be explained based on the JD-R model proposed by Bakker \& Demerouti. This theoretical model demonstrates that the resources owned by the company (job resources) and the resources of the individual (personal resources) interact with the workload of the company (job demands). Bakker \& Demerouti [9] state that job demands are conditions of employees based on workload. The JD-R model assumes that more effort must be exerted to achieve work goals when job demands are high. Job resources function to assist employees in overcoming job demands while at the same time triggering learning, personal development, and growth [10]. Job resources are obtained through interpersonal and social relationships, work arrangements, and work itself [9]. Job resources include wages, support from superiors, feedback, role clarity, job autonomy, or empowerment. Bakker and Demerouti [9] suggest that job resources, job control, and job demands impact employee well-being.

Bakker \& Demerouti [11] personal resources are a positive evaluation of resilience, which refers to an individual's ability to control and positively impact the surrounding environment. One of the personal resources needed by employees is self-leadership. Self-leadership is a variable that shows an individual's ability to control and influence themselves in doing productive things to achieve personal goals [12]. Self-leadership is a process of influencing oneself to build self-direction and motivation in doing or completing tasks so that individual goals can be achieved [22]. 


\section{METHOD}

\subsection{Sample}

This research uses a quantitative method with a causality correlational design. The number of samples in this study was 127 employees. The subjects in this study have the following characteristics: employees who worked during the COVID-19 pandemic in Makassar city.

\subsection{Measurement}

\subsubsection{Dependent Variable}

This scale uses the Likert scale method adapted by Ansar [23], based on the original scale of Houghton \& Neck [22]. The self-leadership questionnaire consists of three parts, part $A$ is the behavioral-focused strategies aspect, part $\mathrm{B}$ is the strategies natural rewards aspect, and part $\mathrm{C}$ is constructive throughout pattern strategies aspect. This self-leadership questionnaire consists of 33 items. After the validity test, the results obtained are RMSEA $0.038<0.08$ and CFI $0.922>0.90$. Reliability test results were obtained by Cronbach's alpha of 0.951 .

\subsubsection{Independent variable}

The subjective well-being variable uses the satisfaction with life scale by Dienner [8] and the scale of positive and negative experiences by Dienner, Wirtz, Biswas, Tov, Kim, Choi, Oishi [24] adapted by Zakiyah (2018). The satisfaction with life scale consists of five items, and the scale of positive and negative experience consists of 12 items, six items for the positive experience, and six items for negative experience. After the validity test, the RMSEA results were $0.06<0.08$ for the satisfaction with life scale and $0.06>0.08$ for the positive and negative experience scale. The reliability test resulted in Cronbach's alpha of 0.829 for the scale of satisfaction with life and 0.483 for the scale of positive and negative experience.

\section{RESULT}

Based on the test results using statistics, the minimum, maximum, mean, and standard deviation values for each variable are shown below.
Table 1. Descriptive Analysis

\begin{tabular}{lcccc}
\hline Variable & $\begin{array}{c}\text { Min. } \\
\text { Value }\end{array}$ & $\begin{array}{c}\text { Max. } \\
\text { Value }\end{array}$ & Mean & SD \\
\hline $\begin{array}{l}\text { Satisfaction } \\
\text { With Life }\end{array}$ & 15 & 35 & 25,64 & 4,97 \\
\hline SPANE & 0 & 16 & 6,69 & 4,03 \\
\hline $\begin{array}{l}\text { Self- } \\
\text { Leadership }\end{array}$ & 99 & 165 & 139,06 & 16,73 \\
\hline
\end{tabular}

The data analysis technique used is simple linear regression analysis, with a significant contribution value of $11.4 \%$ with the value of $r=0.337$ ( $p<0.001$ ) for selfleadership and cognitive aspects of subjective well-being and $8.9 \%$ with the value of $r=0.298(p<0.005)$ for selfleadership and affective aspects of subjective well-being. These results indicate that self-leadership contributes significantly to employees' subjective well-being during the COVID-19 pandemic. Based on the research results, an improvement in self-leadership on employees affects the increase in cognitive and affective subjective wellbeing aspects.

\section{DISCUSSION}

This study aims to determine the contribution of selfleadership to the subjective well-being of employees working in the COVID-19 pandemic situation. Based on the hypothesis test conducted for the variable selfleadership and cognitive aspects of subjective well-being, the significance value obtained is less than 0.05 . The significance value indicates that hypothesis $\mathrm{H} 0$ is rejected and $\mathrm{H} 1$ is accepted, so it can be said that there is a contribution of self-leadership to the cognitive aspects of subjective well-being. Meanwhile, for the hypothesis test conducted for the self-leadership variable and the affective aspect of subjective well-being, the significance value obtained is less than 0.05 . The significance value indicates that hypothesis $\mathrm{H} 0$ is rejected and $\mathrm{H} 1$ is accepted, so it can be said that there is a contribution of self-leadership to the affective aspects of subjective well-being.

Based on the regression data analysis obtained a significant contribution value and is in a positive direction. These results indicate that the increase in self-leadership affects subjective well-being's cognitive and affective aspects. Thus, when employees have high self-leadership, they will be able to increase the employees' subjective well-being, both in terms of cognitive (satisfaction) and affective (emotional) aspects. On the other hand, when employees have low self-leadership, the subjective wellbeing is also low, both in cognitive (satisfaction) and affective (emotional) aspects. 
Self-leadership is a multidimensional construction that influences oneself that aims to increase cognitive resources, namely optimism, purpose and meaning in life, and self-control [22]. Individuals who have selfcontrol get emotional encouragement, motivation, behavior, and physiological strength in the face of an event. Self-control can help individuals achieve what they want and bring satisfaction to their lives [25].

A self-leadership strategy can also increase individual optimism. Optimism is one of the factors that affect subjective well-being. More positive selftalk can help individuals to be more optimistic. Replacing dysfunctional beliefs with more functional, rational, and realistic ones can help individuals be more optimistic and less pessimistic. Doing mental imagery helps increase optimism [26]. Individuals who are optimistic about the future and have high expectations will feel happier and have life satisfaction [25].

The results of this study can be explained using the JD-R theory developed by Bakker \& Demerouti. Employees in carrying out their roles and functions are influenced by their work factors (job resources) and their characteristics (personal resources). The JD-R theory model explains that the resources owned by the company/job (job resources) and the resources of the individual (personal resources) interact with the workload of the company (job demands). When job demands cannot be adequately handled, it will cause stress and burnout. The level of perceived stress can be seen as a challenging situation or obstacle. Stress will be an obstacle when resources are not appropriately met and lead to a low level of well-being.

Conversely, stress will become a challenge when resources are appropriately met and can motivate employees to deal with it, which will lead to a high level of well-being [26]. Challenging demands can affect the level of well-being and engagement [27]. So that job resources and personal resources function to assist individuals in overcoming job demands [10]. Individuals with good personal resources are less prone to experiencing stressful situations [28].

Positive job characteristics (job resources) increase personal resources and improve employee welfare [10]. Xanthopoulou, Bakker, and Demerouti [29] explain that job resources can increase personal resources to enable employees to appear confident, feel capable, satisfied, and happy with the work they do, and experience fewer negative feelings
Personal resources are aspects of self that have a relationship with joy and refer to individual feelings about the ability to impact their environment [29]. Personal resources are positive self-evaluations related to individual resilience and ability to control and positively impact their environment [30]. Research conducted by Judge, Vianen, and De Pater [31] explains that a positive self-evaluation can increase motivation, performance, job satisfaction, life satisfaction. So that the higher the personal resources, the individual will feel and perceive himself as a more positive individual.

Corona Virus Disease in 2019 (COVID-19) has become a global pandemic that has resulted in reduced or limited activities outside the home and almost all offices or companies that implement a work from home system. Employees who work from home have considerable pressure due to new working conditions and a less supportive environment when working from home. So, there is a decrease in employee welfare while working from home. This is in line with the results of research conducted by Pratiwi, Pertiwi, and Andriany [4], which found that the level of subjective well-being of employees who did WFH was at a low level of $39 \%$ and a moderate level of $27 \%$, and a high level of $34 . \%$. The risk of contracting the COVID-19 virus makes individuals feel more negative affect than positive affect because individuals feel threatened by the COVID-19 pandemic.

From this change in a work situation, the company's resources and the individual, in this case, the employees themselves, are not appropriately met. When resources are not appropriately met, it is difficult for employees to cope with the workload. So resources are needed to cope with the workload. When resources from the company (job resources) and resources from individuals (personal resources) are adequate to cope with the workload (job demands), it will support the subjective well-being of employees [32]. Personal resources can affect the subjective well-being of individuals [8].

Personal resources encourage employees to organize reinterpretation to reduce threatening risks. The more workers can reinterpret stressful situations to reduce stress, the higher the level of life satisfaction and experience positive emotions due to a more effective adaptation process [33]. Individuals who can constructively assess the potential threat posed by COVID-19 and utilize personal resources related to selfmeaning will effectively adapt to the situation and maintain a satisfactory level of well-being [34]. Research conducted by Gelanti, Guidetti, Mazzei, Zappala, and Toscano [35] suggests that self-leadership has a positive relationship with productivity and work involvement that 
can maintain productivity and work from home involvement during the COVID-19 pandemic. So that the role of self-leadership as personal resources becomes essential to assist employees in improving subjective well-being while working in the COVID-19 pandemic.

The findings of this study are in line with previous research, which also found a relationship between selfleadership and subjective well-being. Research conducted by [16] explains that self-leadership and subjective well-being have increased entrepreneurial self-development. This study found that selfleadership is the primary key to increasing efficiency and improving entrepreneur performance. Selfleadership is a behavior that is influenced mainly by the individual's internal, so that self-leadership helps individuals increase intrinsic motivation. Individuals with good intrinsic motivation for self-management will experience a stronger sense of well-being and subjective well-being. Research conducted by Dolbier et al. [17] explains that self-leadership is related to the level of health, well-being, and personal resilience. This research proves that self-leadership has a positive impact on the development of individual life.

In addition, research conducted by Malmir and Azizzadeh [36] explains that self-leadership strategies, namely behavioral-focused strategies such as selfobservation and self-assessment, can help individuals realize "who I am" and "what I need to develop." It can help individuals increase positive self-esteem and fight low self-esteem, anxiety, fear, and uncertainty. Positive self-esteem affects subjective well-being because self-evaluation will increase satisfaction in life and happiness. Individuals with positive self-esteem will live their lives positively and believe they can do something effective [25]. This is also in line with research conducted by Uzman \& Maya [18] that there is a positive and significant correlation between the use of strategies self-leadership (behavior focused strategy) aegis and constructive thought pattern strategies) and self-esteem and life satisfaction. Individuals who can lead themselves can control their feelings, thoughts, and behavior. Individuals who control their lives are more involved in activities that satisfy and cause more satisfaction with their lives [29].

D'Intino, Goldsby, Houghton, and Neck [26] also revealed that self-leadership strategies could affect individual emotions. Natural reward strategies help individuals find pleasure and positive emotions in the present moment and the course of work and life by focusing on pleasurable activities. Constructive thought pattern strategies such as positive self-talk, maintenance of functional thought patterns, and mental imagery lead individuals to more optimistic thinking to experience positive emotions to combat feelings of self-neglect, unhappiness, and self-dissociation.

\section{CONCLUSION}

Based on the research results, it can be concluded that self-leadership contributes positively and significantly to subjective well-being. The contribution given by selfleadership is $11.4 \%$ for the cognitive aspect and $8.9 \%$ for the affective aspect. In addition, based on the results of research conducted, it shows that the higher the employee's self-leadership gets, the higher the employee's subjective well-being will be. On the other, the lower the self-leadership, the lower the individual's subjective wellbeing.

\section{AUTHORS CONTRIBUTIONS}

All researchers designed this research topic idea. Author 1 and writer 2 supervised the entire research process, from preparing the proposal to preparing the research report. Author 3 collects data, performs analysis and makes reports. All researchers discussion for the final text

\section{ACKNOWLEDGMENTS}

We thank all those who gave advice and agreed to this research. Thanks to Dr. Muhammad Tamar M.Si and Sri Wahyuni, S.Psi., M.Si., Psikolog, who provided comments and input during the research process. The Department of Psychology supported this work, Faculty of Medicine, Hasanuddin University, and carried out under the psychology code of ethics of the Indonesian Psychological Association (HIMPSI).

\section{REFERENCES}

[1] Insight Talenta. Tiga Distraksi Utama yang Terjadi saat Bekerja di Rumah [Internet]. Accessed on 7 Oktober 2020. Available from: https://www.talenta.co/blog/insight-talenta/3distraksi-utama-yang-terjadi-saat-kerja-di-rumahwfh/.

[2] Aritonang, G. E. Psychological Well-Being Pada Karyawan Work From Home Selama Pandemi Covid-19. Skripsi. 2020. 
[3] Bakker, A. B., \& Oerlemans, W. G. M. Subjective Well-Being in Organizations, (Eds), Handbook of Positive Organizational Scholarship. Oxford University Press. 2010.

[4] Pratiwi, A. M, Pertiwi, M. Andriany, A. R. Hubungan Subjective Well-Being Dengan Komitmen Organisasi Pada Pekerja Yang Melakukan Work From Home di Masa Pandemi Covid 19. 2020. 2 (11).

[5] Diener, E., Lucas, R. E., dan Oishi, S. Subjective Well Being: The Science of Happiness and Life Satisfaction. Handbook of Positive Psychology. NC: Oxford University Press. 2005.

[6] Diener, E., \& Scollon, C. Subjective Well-Being is Desirable, But Not The Summum Bonum. Subjective Well-Being. Minneapolis: University of Minnesota. 2003.

[7] Diener, E., Sandvik, E., Pavot, W. Happiness is The Frequency, Not The Intensity, of Positive Versus Negative Affect. In F. Strack, M. Argyle \& N. Schwarz (Eds.). Subjective Well-Being: An Interdisciplinary Perspective. New York: Pergamo. 1991. 119 - 139.

[8] Diener, E. Subjective Well-being. Psychological Bulletin. 1984. 95(3), 542 - 575

[9] Bakker A., B., \& Demerouti, E. The Job Demands-Resources Model: State of the Art. Journal of Managerial Psychology. 2007. 22(3). $309-328$.

[10] Demerouti, E., Bakker, A.B., Nachreiner, F. \& Schaufeli, W.B. The Job Demands-Resources Model of Burnout. Journal of Applied Psychology. 2001. 86, No. 3, 499 - 512.

[11] Bakker, A. B., \& Demerouti, E. Towards a model of work engagement. Career Development International. 2008. 13(3), 209 - 223.

[12] Manz, C. C. Self Leadership: Toward an Expanded Theory of Self-influence Processes in Organizations. Academy of Management Review. 1986. 11(3), 585 - 600.

[13] Manz, C., \& Sims, H. Super Leadership: Beyond the Myth of Heroic Leadership. Organizational Dynamics. 1991. 19, $18-35$.

[14] Sesen, H., Tabak, A., \& Arli, O. Consequences of Self Leadership: A Study on Primary School Teachers. Educational Sciences: Theory and Practice. 2017. 17 (3), 945 - 986.
[15] Rahmawaty, D. \& Rochmah, T.N. Pengaruh Kompetensi dan Self Leadership terhadap Kinerja Petugas Program Pengendalian Tuberkulosis (P2tb) Puskesmas di Kabupaten Jamber. Jurnal Administrasi Kesehatan Indonesi. 2014. 2 (3).

[16] Kontonen, M. The Role of Self-Leadership in Personal Development of an Entrepreneur. A Qualitative Study on Wellbeing Entrepreneurs. Lund University. 2019.

[17] Dolbier, C. L., Soderstrom, M., \& Steinhardt, M. A. The Relationship Between Self Leadership and Enhanced Psychological, Health, and Work Outcomes. The Journal of Psychology. 2001. 135 (5), $449-485$.

[18] Uzman, R \& Maya, I. Self-Leadership Strategies as The Predictor of Self-Esteem and Life Satisfaction in University Students. International Journal of Progressive Education. 2019. 15 (2). 78 - 90.

[19] Diener, E., Suh, E. M., Lucas, R. E., \& Smith, H. L. Subjective Well-being: Three Decades of Progress. Psychological Bulletin. 1999.

[20] Ariati, J. Subjective Well Being (Kesejahteraan Subjektif) dan Kepuasan Kerja pada Staff Pengajar (Dosen) di Lingkungan Fakultas Psikologi Universitas Diponegoro. Jurnal Psikologi Undip. Semarang: Universitas Diponegoro. 2010. 8, (2).

[21] Prussia, G. E., Anderson, J. S., \& Manz, C. C. SelfLeadership and Performance Outcomes: The Mediating Influence of Self-Efficacy. Journal of Organizational Behavior: The International Journal of Industrial, Occupational and Organizational Psychology and Behavior. 1998. 19(5), 523 - 538.

[22] Houghton, J. D., \& Neck, C. P. The Revised Self Leadership Questionnaire: Testing a Hierarchical Factor Structure for Self Leadership. Journal of Managerial Psychology. 2002. 17(8), 672 - 691.

[23] Ansar, N. Konstruksi Skala Self Leadership. Universitas Hasanuddin. Skripsi. 2020.

[24] Zakiyah, S. N. Kontribusi Workplace Relationship terhadap Subjective Well-Being pada Perawat di RSIA X Makassar. Skripisi. 2018.

[25] Compton, W. C. An Introduction to Positive Psychology. USA: Thomson Learning, Inc. 2005.

[26] D‘Intino, R.S, Goldsby,M. G, Houghton, J. D, Neck, C. P. Self-Leadership: A Process for Entrepreneurial Success. Journal Of Leadership and Organisational Studies. 2007. 13: 24-32. 
[27] Crawford, E.R., Lepine, J.A. And Rich, B.L. Linking Job Demands and Resources to Employee Engagement and Burnout: A Theoretical Extension and Meta-Analytic Test, Journal of Applied Psychology. 2010. 95 No. 5, 834-848.

[28] Yang, H., Choi, B., Kim, A. \& Kim, J. Illusion of Control? or Posttraumatic Growth? Influencing Factors Between Risk Controllability and Satisfaction on Subjective Life. International Journal of Social Welfare Promotion and Management. 2016, 3, 161-166.

[29] Xanthopoulou, D, Bakker, AB, Demerouti, E. The Role of Personal Resources in the Job Demands-Resources Model. International Journal of Stress Management. 2007. 14(2): 121141.

[28] Hobfoll, S. E. Conservation of Resources: A New Attempt at Conceptualizing Stress. American Psychologist. 1989. 44 (3), 513-524.

[30] Hobfoll, S. E., Johnson, R. J., Ennis, N., \& Jackson, A. P. Resource Loss, Resource Gain, and Emotional Outcomes Among Inner City Women. Journal of Personality and Social Psychology. 2003. 84, 632-643.

[31] Judge, T.A., Van Vianen, A.E.M. \& De Pater, I. Emotional Stability, Core Self-Evaluations, and Job Outcomes: A Review of the Evidence and an Agenda for Future Research. Human Performance. 2004. 17, 325-46.

[32] Robbins, P. S. Perilaku Organisasi. Edisi Sepuluh. Diterjemahkan oleh: Drs. Benyamin Molan. Erlangga; Jakarta. 2006.

[33] Park, C.L. Meaning Making in the Context of Disasters: Meaning Making in the Context of Disasters. J. Clin. Psychol. 2016. 72, 1234-1246.

[34] Krok, D.; Zarzycka, B. Risk Perception Of COVID-19, Meaning-Based Resources and Psychological Well-Being Amongst Healthcare Personnel: The Mediating Role of Coping. J. Clin. Med. 2020. 9, 3225.

[35] Galanti, T. Guidetti, G. Mazzei, E. Zappala, S. Toscano, F. Work From Home During the COVID-19 Outbreak the Impact on Employees' Remote Work Productivity, Engagement, and Stress. J Occup Environ Med. 2021. 63 (7). 426 432.
[36] Malmir, A \& Azizzadeh, F. Evaluation of SelfLeadership Statue and Providing Solutions to Improve Self-leadership Statue. International Journal of Managing Public Sector Information and Communication Technologies. 2013. 4:1-16. 